\title{
Herpes simplex virus type 2 encephalitis and concomitant cytomegalovirus infection in a patient with AIDS: detection of virus-specific DNA in CSF by nested polymerase chain reaction
}

\author{
R F Miller, J D Fox, J C Waite, A Severn, N S Brink
}

\begin{abstract}
A Caucasian homosexual man with AIDS and cytomegalovirus retinitis presented with facial pain and episodic confusion, had several seizures and became obtunded. An electroencephalogram was suggestive of herpes simplex encephalitis. The diagnosis was confirmed by detection of herpes simplex virus type 2 (HSV 2 ), but not type 1, DNA in cell-free cerebrospinal fluid (CSF) after amplification by nested polymerase chain reaction. The patient also had evidence of concomitant cytomegalovirus (CMV) infection with detectable CMV DNA in CSF. With highdose acyclovir the patient recovered. Analysis of a follow up CSF sample taken four months later showed no detectable HSV-2 DNA.
\end{abstract}

(Genitourin Med 1995;71:262-264)

Keywords: Herpes simplex virus type 2; encephalitis; AIDS; PCR

\section{Introduction}

Herpes simplex virus (HSV) is the commonest cause of severe focal encephalitis in man, ${ }^{1}$ with an annual incidence in the USA of 1 in 200,000 . Over $90 \%$ of all herpes simplex encephalitis (HSE) is due to HSV-1. The clinical patterns of neurological disease associated with HSV-1 and 2 infections may vary with a focal encephalitis usually being associated with HSV-1 infection. In contrast to this HSV-2, is more frequently associated with meningitis or myelitis with encephalitis occurring less frequently. ${ }^{2}$ Herpes simplex encephalitis is characterised by progressive cerebral necrosis and oedema, with more than $70 \%$ mortality if untreated. ${ }^{3}$ Use of specific antiviral therapy (acyclovir) results in a significant reduction in mortality. In addition, $65 \%$ of patients receiving acyclovir therapy have no residual neurological deficit or only mild impairment. ${ }^{3}$

Clinical criteria alone cannot be used to make a diagnosis of herpes simplex encephalitis, as diseases including other viral encephalitides and bacterial infections, for example tuberculous meningitis, may give similar symptoms and signs. ${ }^{4}$ In the past, brain biopsy has been necessary to make a definitive diagnosis as viral culture of cerebrospinal fluid (CSF) only confirms a diagnosis of HSE in the minority (4\%) of brain biopsy proven cases. ${ }^{5}$ Tests for HSV-1 antigen lack sensitivity and intrathecal synthesis of HSV specific antibody is usually only detectable 7-10 days after the onset of illness. ${ }^{67}$ Profoundly immunosuppressed patients, for example those with AIDS, may also have a suboptimal antibody response. The polymerase chain reaction (PCR) has been used to amplify and detect HSV-1 DNA in CSF of patients with HSE. ${ }^{289}$ We have developed methods for amplification and detection of herpesviral DNA including cytomegalovirus (CMV), HSV-1, HSV-2 and varicella-zoster virus (VZV) and report here use of the technique to detect HSV-2 DNA in CSF from a patient with AIDS who presented with encephalitis and in whom viral culture was negative.

Case report

A 59 year old Caucasian homosexual man was admitted, as an emergency, in November 1993 reporting loss of visual acuity in the left eye, left sided burning facial pain with skin tenderness and abnormal sensation and episodic confusion and disorientation for three days. Soon after admission he became obtunded and had several generalised tonicclonic convulsions.

The patient was diagnosed as HIV-infected in 1985 and had a past medical history of syphilis, gonorrhoea and non-specific urethritis but not labial or anogenital herpes simplex infection. In August 1992 he had an episode of Pneumocystis carinii pneumonia (his AIDS defining diagnosis) and subsequently began secondary anti-pneumocystis prophylaxis with co-trimoxazole $960 \mathrm{mg}$ once daily. At this time the patient was profoundly immunosupressed with a CD4 count of $0.02 \times 10^{9} / 1$ (NR $\left.=0.35-2.2 \times 10^{9} / 1\right)$. He had remained well until July 1993, when he presented with a seven week history of numbness in both feet and a one week history of reduced visual acuity in the right eye. On examination there was clinical evidence of $\mathrm{CMV}$ retinitis affecting the right eye. Investigations included nerve conduction studies which showed a mild sensorimotor neuropathy in the feet and cranial magnetic resonance imaging (MRI) showed mild diffuse cortical atrophy and early white matter changes indicative of HIV encephalopathy together with paranasal sinus disease. At lumbar puncture (July 1993) CSF analysis showed no cells, protein $=0.9 \mathrm{~g} / \mathrm{l}$, glucose $=2.3 \mathrm{mmol} / \mathrm{l}$ (simultaneous plasma glucose $=5.4 \mathrm{mmol} / \mathrm{l}$ ). Staining and culture 
Detection of viral DNA in cell-free supernatant of CSF

\begin{tabular}{|c|c|c|c|}
\hline & Fuly 1993 & November 1993 & March 1994 \\
\hline Clinical diagnosis & $\begin{array}{l}\text { CMV retinitis } \\
\text { Sensorimotor } \\
\text { neuropathy }\end{array}$ & $\begin{array}{l}\text { Encephalitis } \\
\text { Recurrence of } \\
C M V \text { retinitis }\end{array}$ & $\begin{array}{l}\text { HIV } \\
\text { encephalopathy }\end{array}$ \\
\hline $\begin{array}{l}\text { "Nested" PCR results } \\
\text { HSV-1 } \\
\text { HSV-2 } \\
\text { CMV } \\
\text { VZV }\end{array}$ & $\begin{array}{l}\text { Not detected } \\
\text { Not detected } \\
\text { Not detected } \\
\text { Not detected }\end{array}$ & $\begin{array}{l}\text { Not detected } \\
+ \\
+ \\
\text { Not detected }\end{array}$ & $\begin{array}{l}\text { Not detected } \\
\text { Not detected } \\
+ \\
\text { Not detected }\end{array}$ \\
\hline
\end{tabular}

Key: $\mathrm{HSV}=$ Herpes simplex virus; VZV = Varicella zoster virus; $\mathrm{CMV}=$ Cytomegalovirus.

for bacteria, mycobacteria, fungi and viruses was negative. Cryptococcal antigen was not detected in blood or CSF and serological tests for syphilis and toxoplasmosis were negative in CSF and blood. There was no detectable CMV, VZV, HSV-1 or HSV-2 DNA in CSF (see below and table). A Hickman line was inserted and the patient was started on ganciclovir therapy which was changed to foscarnet after the development of thrombocytopenia. During this admission the patient had a second episode of pneumocystis pneumonia, which was treated with clindamycin and primaquine. Following discharge from hospital he remained well on maintenance foscarnet therapy $(80 \mathrm{mg} / \mathrm{kg} /$ day) until readmission in November 1993.

On readmission the patient had evidence of CMV retinitis in the left eye with no objective sensory deficit of the face. Foscarnet therapy was increased to treatment doses (180 $\mathrm{mg} / \mathrm{kg} /$ day) and ganciclovir $10 \mathrm{mg} / \mathrm{kg} /$ day was added. The day after admission the patient became obtunded and had several generalised tonic-clonic seizures. Investigations showed normal urea and electrolyte levels, liver function and calcium and phosphate levels. MRI showed more marked cortical atrophy and diffuse white matter signal abnormality. An electroencephalogram (EEG) was suggestive of HSE with diffuse slowing in theta and delta ranges and absence of normal rhythms suggesting generalised disturbance of cerebral function. In addition, there was a prominent epileptiform spike focus in the right occipital region and runs of semi-periodic sharp waves and sharp-slow wave complexes were seen in the left temporal region. At lumbar puncture CSF analysis showed no cells, protein $=0.7$ $\mathrm{g} / 1$ and glucose $=2.3 \mathrm{mmol} / 1$ (simultaneous plasma glucose $=5.6 \mathrm{mmol} / \mathrm{l}$ ). Staining and culture for bacteria, mycobacteria, fungi and viruses and cryptococcal antigen estimation were all negative. Both HSV-2 and CMV-specific DNA sequences were detected in the CSF using selective DNA amplification (see below). No detectable HSV-1 or VZV DNA was present.

Intravenous ganciclovir was continued at a dose of $10 \mathrm{mg} / \mathrm{kg} / \mathrm{day}$, the foscarnet discontinued and intravenous acyclovir was added $(10 \mathrm{mg} / \mathrm{kg} 8$ hourly). Phenytoin was given in order to prevent further fits and with this treatment the patient dramatically improved and became alert and orientated. Formal neurological examination after the completion of acyclovir therapy revealed no focal deficit. The CMV retinitis in the left eye also responded clinically to treatment. A repeat EEG after 23 days of treatment remained abnormal with a generalised excess of slow wave activity and prominent spike-sharp-slow wave complexes in the left posterior temporal region. Acyclovir was discontinued after 24 days of treatment but the patient remained on maintenance dosage of intravenous ganciclovir to prevent progression of CMV retinitis. $\mathrm{He}$ was then discharged home where he remained self-caring until he was readmitted in March 1994 when he presented with a short history of confusion and a mild expressive dysphasia. Cranial MRI showed marked cortical atrophy and extensive white matter changes in the posterior fossa consistent with HIV encephalopathy. Analysis of CSF obtained at lumbar puncture showed no cells, protein $=0.5 \mathrm{~g} / 1$ and glucose $=2.2 \mathrm{mmol} / 1$ (simultaneous plasma glucose $=4.9 \mathrm{mmol} / \mathrm{l}$ ). Staining and culture were negative for bacteria, mycobacteria, fungi and viruses. Herpes simplex virus types 1 and 2 and VZV DNA was not detected in the CSF after nested PCR. However, detectable CMV DNA was still present (table). Over the next few days the patient's condition steadily deteriorated; he declined further investigation and at his request was transferred to a hospice where he died three weeks later. Necropsy was not performed.

\section{"Nested" PCR amplification}

The "nested" PCR used utilises oligonucleotide primers to detect $\mathrm{CMV} g B, \mathrm{VZV}$ gene 29, HSV-1 $g D$ and HSV-2 $g G$ sequences. ${ }^{9-11}$ This was applied to the CSF samples from our patient to detect cell-free herpesvirus specific DNA. The CSF samples were pelleted (15000 $\mathrm{g}$, five minutes), the supernatant was boiled for 10 minutes then cooled on ice. First round nested PCR was carried out in a $50 \mu \mathrm{l}$ mixture containing $10 \mathrm{mM}$ Tris- $\mathrm{HCl} \mathrm{pH} 8 \cdot 3$, $50 \mathrm{mM} \mathrm{KCI}, 1.5 \mathrm{mM} \mathrm{MgCl}{ }^{2}, 1$ unit of Taq polymerase (Applied Biosystems, London), $200 \mu \mathrm{M}$ of each dNTP, $100 \mathrm{ng}$ of each "outer" primer and $10 \mu \mathrm{l}$ of CSF supernatant. After an initial four minutes denaturation at $94^{\circ} \mathrm{C}, 35$ cycles of $94^{\circ} \mathrm{C}$ for two minutes, $58^{\circ} \mathrm{C}$ (CMV) or $60^{\circ} \mathrm{C}$ (HSV-1, HSV-2, VZV) for two minutes and $72^{\circ} \mathrm{C}$ for one minute were carried out followed by a seven minute extension at $72^{\circ} \mathrm{C}$ using an $\mathrm{MJ}$ Research PTC-100 automated thermal cycler (GRI Ltd, Essex). The reaction mixture for second round PCR was the same as for the first except $200 \mathrm{ng}$ of each "inner" primer was used instead of the "outer" primers and $1 \mu 1$ of the first round product was the source of DNA. The thermal cycling for the second round reaction was 25 cycles of $94^{\circ} \mathrm{C}$ for two minutes, $50^{\circ} \mathrm{C}$ for two minutes and $72^{\circ} \mathrm{C}$ for one minute followed by a seven minute extension at $72^{\circ} \mathrm{C}$. Products of PCR amplification were analysed by ethidium bromide stained agarose gel electrophoresis. Appropriate positive and negative controls (both CSF and distilled water) were included in each PCR run. 


\section{Discussion}

Our case has several interesting aspects. Firstly HSV-2 is an unusual cause of encephalitis, the majority of cases are due to HSV-1, with HSV-2 being more commonly associated with an aseptic meningitis or myelitis. In a previous report of two cases of HSE due to HSV-2 in HIV-infected homosexual men the diagnosis was made by culture and detection of HSV-2 specific antigen in brain biopsy material. ${ }^{12}$ Both patients received specific antiviral therapy, but had severe residual neurological deficits. In contrast, our patient had no apparent neurological deficit on recovery, possibly because of the rapid therapeutic intervention with high dose of intravenous acyclovir. However, his EEG remained abnormal for some time, a feature that is well described in HSE. ${ }^{13}$

The patient described in this report had no previous history of labial or anogenital lesions. Possible explanations for this are that the patient had a primary asymptomatic HSV-2 infection in the past with subsequent reactivation of latent virus and development of an encephalitic illness or, alternatively, developed HSE complicating a primary HSV-2 infection. In a recent study 4 of 6 immunocompetent patients with HSE due to HSV-2 demonstrated a $g G-2$ specific antibody seroconversion indicating a primary $\mathrm{HSV}-2$ infection. ${ }^{2}$ We did not perform HSV-2-specific serology on our patient and are therefore uncertain as to whether his HSE resulted from a primary infection or reactivation of latent virus.

We have developed methods for detection of several herpesviruses in clinical samples. ${ }^{14-17}$ As nested PCR will detect small amounts of viral genome there is concern that contamination of CSF with virus contained in peripheral blood cells may give false positive results. We do not consider this to be a problem in our patient as, firstly, we examined cell-free CSF supernatants for the presence of herpesviral DNA and secondly, there was an appropriate association between the presence of detectable HSV-2 DNA and the patient's encephalitic illness. In addition to this, there was no detectable HSV-2 DNA in the CSF samples taken four months before presentation and after recovery (table). The latter finding is consistent with reports which demonstrate that detectable HSV-1 DNA disappears from the CSF of patients with HSE between one and four weeks after clinical response to treatment. ${ }^{9}$

We have reported previously that a diagnosis of CMV retinitis without further neurological involvement, such as polyradiculopathy or encephalopathy, is not associated with detectable CMV DNA in CSF. ${ }^{18}$ It is therefore not surprising that CSF taken from our patient on initial presentation at the time of diagnosis of $\mathrm{CMV}$ retinitis, contained no detectable CMV DNA as at this stage the patient had no evidence of an encephalopathy. However, both of the subsequent samples (the first taken at the time of diagnosis of HSE and the second four months later) con- tained CMV-specific sequences. It is difficult to assess the contribution of the CMV infection of the nervous system to the patient's preterminal neurological deterioration. However, an association between detection of CMV DNA in CSF and neurological disease, including encephalopathy, in patients with AIDS has been described. ${ }^{17}$

In conclusion, the definitive laboratory diagnosis of HSE in our patient was made by detection of HSV-2 specific sequences in the CSF by nested PCR. Nested PCR is a highly sensitive and specific method of diagnosis of HSE and obviates the need for brain biopsy. The role of CMV in this patient's neurological disease is less clear but this concomitant viral infection may well have contributed to the patient's preterminal neurological deterioration.

Dr J D Fox is a Wellcome Trust Vision Research Fellow.

1 Whitely RJ, Gnann JW Jr. The epidemiology and clinical manifestations of herpes simplex virus infections. In: manifestations of herpes simplex virus infections. In: Herpesviruses. New York: Raven Press Ltd 1993:69-105.

2 Aurelius E, Johansson B, Skoldenberg B, Forsgren M. Encephalitis in immunocompetent patients due to herpes simplex virus type 1 or 2 as determined by typespecific polymerase chain reaction and antibody assays of the cerebrospinal fluid. $\mathcal{F}$ Med Virol 1993;39:179-86.

3 Whitely RJ, Gnann JW. Antiviral Therapy. In: Roizmann B, Whitely RJ, Lopez C, Eds. The Human Herpesviruses. New York: Raven Press Ltd 1993:329-48.

4 Whitely RJ, Cobbs CG, Alford CA, et al. Diseases that mimic herpes simplex encephalitis. $\mathcal{F A M A} 1989 ; 262$ : 234-9.

5 Nahmias AJ, Whitely RJ, Visintine AN, et al. Herpes simplex virus encephalitis; laboratory evaluations and their plex virus encephalitis; laboratory evaluations and the

6 Lakeman FD, Koja J, Whitely RJ. Detection of antigen to herpes simplex virus in cerebrospinal fluid from patients with herpes simplex encephalitis. $\mathcal{F}$ Infect Dis $1987 ; 155$ 1172-8

7 Kahlon J, Chatterjee S, Lakeman FD, Lee F, Nahmias AJ, Whitely RJ. Detection of antibodies to herpes simplex virus in the cerebrospinal fluid of patients with herpes simplex encephalitis. $\mathcal{F}$ Infect Dis 1987;115:38-44.

8 Rowley AH, Whitely RJ, Lakeman FD, Wolinsky SM. Rapid detection of herpes simplex virus DNA in CSF of patients with herpes simplex encephalitis. Lancet 1990; patients with 1 33:440-1.

9 Aurelius E, Johansson B, Skoldenberg B, Staland A Fosgren M. Rapid diagnosis of herpes simplex encephalitis by nested polymerase chain reaction on cerebrospinal fluid. Lancet 1991;337:189-92.

10 Mahalingham $R$, Wellish $M$, Wolf W, et al. Latent varicella-zoster DNA in human trigeminal ganglion. $N$ Engl $\mathcal{F}$ Med 1990;323:627-31.

11 Darlington J, Super M, Patel K, et al. Use of the polymerase chain reaction to analyse sequence variation in the major neutralising epitope of glycoprotein B (op 58) in clinical isolates of human cytomegalovirus. $f \mathrm{Gen}$ Virol 1991;72:1985-9.

12 Dix RD, Waitzman DM, Follansbee $S$, et al. Herpes simplex type 2 encephalitis in two homosexual men with simplex type 2 encephalitis in two homosexual men with persiste

13 Illis LS, Taylor FM. The electroencephalogram in herpes simplex encephalitis. Lancet 1972;i:718-21.

14 Grant AD, Fox JD, Brink NS, Miller RF. Detection of varicella-zoster virus DNA using the polymerase chain reaction in an immunosupressed patient with transverse myelitis secondary to herpes zoster. Genitourin Med 1993;69:273-5.

15 Wakefield AJ, Fox JD, Sawyer AM, et al. Detection of herpesvirus DNA in the large intestine of patients with ulcerative colitis and Crohn's disease using the with ulcerative colitis and Crong

16 Mitchell SM, Fox ID, Tedder RS, Gazzard B, Lightman S. Vitreous sampling and viral genome detection for the diagnosis of viral retinitis. $f$ Med Virol 1994;40:336-40.

17 Fox JD, Zuckerman MA, Waite JC, Brink NS, Gazzard BG, Miller RF. Correlation of CMV DNA detection in BG, Miller RF. Correlation of CMV DNA detection in CSF with neurological disease in patients with AIDS.
Abstract. The 19th International Herpesvirus Workshop, Vancouver August 1994.

18 Mitchell SM, Fox JD, Gazzard HG, Lightman SL, Tedder RS. Correlation of herpesvirual DNA detection in ocular samples and CSF with retinal disease in immunocompetent and immunosuppressed patients. Abstract. The 19th International Herpesvirus Workshop, Vancouver August 1994. 